\title{
Evaluasi Kinerja dan Konsumsi Energi Pengering Pati Sagu Model Agitated Fluidized Bed Bertenaga Biomassa
}

\section{Evaluation of Performance and Energy Consumption of Agitated Fluidized Bed Sago Starch Dryer Model Powered of Biomass}

\author{
Abadi Jading $^{1 *}$, Paulus Payung ${ }^{2}$, Eduard Fransisco Tethool ${ }^{3}$ \\ 1,2 Jurusan Teknik Pertanian dan Biosistem, Fakultas Teknologi Pertanian Unipa \\ Jl. Gunung Salju amban, Manokwari 98314. \\ ${ }^{3}$ Jurusan Teknologi Hasil Pertanian, Fakultas Teknologi Pertanian Unipa \\ Jl. Gunung Salju amban, Manokwari 98314. \\ "Email: a.jading@unipa.ac.id
}

\begin{abstract}
Agitated Fluidized Bed (AFB) dryers have been designed for drying sago starch. To find out the performance of the AFB dryer, an analysis of the Heat Utilization Factor (HUF), Coefficient Of Performance (COP), Effective Heat Efficiency (EHE), and Specific Energy Consumption (SEC) performance index results based on temperature treatment $\left(50^{\circ} \mathrm{C}, 60^{\circ} \mathrm{C}\right.$, and $\left.70^{\circ} \mathrm{C}\right)$ and material input mass ( $3 \mathrm{~kg}, 6 \mathrm{~kg}$ and $12 \mathrm{~kg})$. The HUF, COP, EHE and SEC performance index values are determined by mathematical analysis. The results of this study indicate that, the best AFB dryer performance index of all temperature treatments and material input mass is at $60^{\circ} \mathrm{C}$ with a material input mass of $12 \mathrm{~kg}$, where the HUF value is greater than the COP value. The HUF, COP, and EHE values were $53.1 \%, 46.9 \%, 70.3 \%$ and SEC values $559.9 \mathrm{~kJ} / \mathrm{s}$. The average values of HUF, COP, EHE, and SEC of all treatments in the AFB dryer were $37.23 \%, 62.7 \%, 58.5 \%$, and $337.6 \mathrm{~kJ} / \mathrm{s}$. This shows that the $A F B$ dryer performance is quite low, where the average HUF value is smaller than the average COP value, and the energy used is quite high. However, AFB dryers were able to dry sago starch with a final moisture content of $14.4 \%$ wet basis approaching the quality standard of dry sago starch 13\%, at a temperature of $70^{\circ} \mathrm{C}$ with a mass of material as much as $3 \mathrm{~kg}$ for 5 minutes (300 seconds).
\end{abstract}

Keywords: agitated fluidized bed, dryer, performance index, sago.

\begin{abstract}
Abstrak
Pengering Agitated Fluidized Bed (AFB) telah dirancang untuk pengeringan pati sagu. Untuk mengetahui kinerja pengering AFB tersebut, maka dilakukan analisis nilai indeks kinerja Heat Utilization Factor (HUF), Coefficient Of Performance (COP), Effective Heat Efficiency (EHE), dan Specific Energy Consumption (SEC) berdasarkan perlakuan suhu $\left(50^{\circ} \mathrm{C}, 60^{\circ} \mathrm{C}\right.$, dan $\left.70^{\circ} \mathrm{C}\right)$ dan massa input bahan $(3 \mathrm{~kg}, 6 \mathrm{~kg}$, dan $12 \mathrm{~kg})$. Nilai indeks kinerja HUF, COP, EHE dan SEC ditentukan dengan analisis matematis. Hasil penelitian ini menunjukkan bahwa indeks kinerja pengering AFB terbaik dari semua perlakuan suhu dan massa input bahan adalah pada suhu $60^{\circ} \mathrm{C}$ dengan massa input bahan $12 \mathrm{~kg}$, dimana nilai HUF lebih besar dari nilai COP. Nilai HUF, COP, dan EHE masing-masing adalah $53,1 \%, 46,9 \%, 70,3 \%$ dan nilai SEC 559,9 kJ/s. Nilai rata-rata HUF, COP, EHE, dan SEC dari semua perlakuan pada pengering AFB adalah 37,23\%, 62,7\%, 58,5\%, dan 337,6 kJ/s. Kinerja pengering AFB cukup rendah, dimana nilai HUF rata-rata lebih kecil dari nilai COP rata-rata, dan energi yang digunakan cukup tinggi. Namun demikian, pengering AFB mampu mengeringkan pati sagu dengan kadar air akhir $14,4 \%$ basis basah mendekati standar mutu pati sagu kering $13 \%$, pada suhu $70^{\circ} \mathrm{C}$ dengan massa bahan sebanyak $3 \mathrm{~kg}$ selama 5 menit (300 detik).
\end{abstract}

Kata kunci:, agitated fluidized bed, pengering, indeks kinerja, sagu 


\section{PENDAHULUAN}

Alat pengeringan pati sagu model agitated fluidized bed (AFB) merupakan pengembangan dari alat pengering agitatedvibro fluidized bed (AGROFB) yang telah dikembangkan sebelumnya oleh Jading dkk. (2014a) dan Jading dkk. (2017a). Alat Pengering AFB merupakan pengering buatan sehingga mampu mengeringkan pati sagu basah lebih cepat, apabila dibandingkan dengan pengering konvensional atau penjemuran yang menggunakan sumber panas sinar matahari (Jading dkk., 2015). Pengembangan pengering AFB dimaksudkan untuk meningkatkan kinerja pengering AGROFB dengan memisahkan sistem pengaduk (agitator) dan penggetar (vibrator) di dalam ruang pengeringan. Menurut Jading dkk. (2014a) pengering AGROFB memiliki kinerja yang sangat rendah yaitu efisiensi pengeringan 4,9\%, kapasitas $35 \mathrm{~kg}$ pati basah per proses, waktu operasi 6 jam, rendemen bahan 50\%, dan konsumsi bahan bakar biomassa (tempurung kelapa) $70 \mathrm{~kg}$ atau 11,67 kg/jam, serta mampu menurunkan kadar air pati sagu basah dari $45 \%$ basis basah (bb) menjadi $14,7 \%$ bb.

Penambahan agitator pada pengering sangat efektif untuk mengurai bongkahan pati sagu basah, sehingga mudah terangkat oleh udara panas secara fluidisasi. Agitator mampu mengalirkan bahan secara optimum di dalam silinder pengering dengan persentase bahan yang terangkat sebesar 99\% (Jading dkk., 2013). Oleh karena itu, Jading dkk. (2015) telah mengembangkan pengering AFB untuk pengeringan pati sagu basah berbahan bakar biomassa. Untuk mengetahui nilai indeks kinerja pengering $\mathrm{AFB}$, maka dilakukan analisis matematis dengan menentukan Heat Utilization Factor (HUF), Coefficient of Performance (COP), Effective Heat Efficiency (EHE), dan jumlah energi spesifik atau Specific Energy Consumption (SEC) yang digunakan selama proses pengeringan. Sedangkan analisis kinerja pengering AFB berdasarkan efisiensi panas dan efisiensi pengeringan, serta mutu bahan kering tidak diuraikan dalam pembahasan ini.

Nilai HUF adalah rasio penurunan suhu akibat pendinginan udara selama pengeringan dan peningkatan suhu akibat pemanasan udara
(Sayyed dkk., 2015). Sedangkan nilai COP yaitu rasio antara selisih suhu udara keluar dari pengering dengan suhu lingkungan terhadap selisih suhu udara pengering dengan suhu lingkungan. Menurut Pradhapraj dan Velmurugan (2014), hubungan antara HUF dengan COP adalah bernilai satu (HUF $=1-$ COP), artinya bahwa semakin besar nilai HUF maka semakin kecil nilai COP, oleh karena itu, nilai indeks suatu pengering semakin tinggi atau kinerja pengering tersebut sangat baik. Nilai HUF dan COP mempengaruhi nilai EHE yang digunakan selama proses pengeringan. Nilai EHE merupakan panas sensibel dalam udara pengeringan, yaitu panas yang efektif untuk pengeringan (Chakraverty dan De, 1981). Besarnya nilai HUF, COP, dan EHE juga mempengaruhi jumlah energi yang dibutuhkan oleh suatu pengering. Jumlah kebutuhan energi pengering ditentukan berdasarkan nilai SEC (Nimmol dan Devahestin, 2010). Tujuan penelitian ini adalah menganalisis nilai indeks kinerja HUF, COP, EHE dan kebutuhan energi SEC pengering AFB secara matematis berdasarkan perlakuan suhu dan massa (bobot) input bahan.

\section{METODOLOGI}

Penelitian ini dilaksanakan di Bengkel Agroindustri, Laboratorium Teknologi Pertanian, Fakultas Teknologi Pertanian, Universitas Papua mulai bulan Februari sampai Oktober 2015.

Bahan yang digunakan pada penelitian ini adalah pati sagu basah diperoleh dari hasil pengolahan sagu rakyat di Kabupaten Wondama Papua Barat. Kadar air awal pati sagu basah yang digunakan saat pengujian pengering AFB adalah $37 \%$ basis basah (bb). Alat yang digunakan pada penelitian ini adalah pengering AFB yang dilengkapi tungku biomassa berbahan bakar tempurung kelapa, dan beberapa alat ukur seperti termometer digital untuk mengukur suhu lingkungan dan udara pengering, air flow meter untuk mengukur kecepatan udara pengering, $\mathrm{RH}$ meter untuk mengukur kelembaban lingkungan, dan beberapa alat pendukung lainnya.

Variabel perlakuan (yang divariasi) selama pengujian pengering $\mathrm{AFB}$ adalah suhu udara pengering $\left(\mathrm{T}_{\mathrm{u}}\right)$ yaitu $50^{\circ} \mathrm{C}, 60^{\circ} \mathrm{C}$, dan 
$70^{\circ} \mathrm{C}$ dan massa awal bahan atau bahan input pati sagu basah $\left(\mathrm{m}_{\mathrm{ib}}\right)$ yaitu $3 \mathrm{~kg}, 6 \mathrm{~kg}$, dan 12 $\mathrm{kg}$, sedangkan kadar air awal bahan $\left(\mathrm{M}_{\mathrm{ib}}\right)$ dianggap konstan yaitu $37 \%$ bb. Setiap variabel perlakuan yang dilakukan sebanyak 3 variasi, dan 3 kali ulangan. Variabel pengamatan meliputi suhu udara yang keluar dari pengering $\left(\mathrm{T}_{\mathrm{op}}\right)$, suhu udara luar atau lingkungan $\left(\mathrm{T}_{\text {ling }}\right)$, kelembaman relative $(\mathrm{RH})$ lingkungan, massa bahan bakar biomassa selama pengeringan $\left(\mathrm{m}_{\mathrm{bb}}\right)$, waktu pengeringan (t), dan kadar air akhir bahan $\left(\mathrm{M}_{\mathrm{ob}}\right)$. Sedangkan kecepatan udara fluidisasi, kecepatan putaran silinder pengumpan, dan kecepatan putaran agitator dianggap konstan.

\section{Prosedur Pengujian}

Sampel pati sagu basah yang diumpankan ke dalam pengering AFB sebagai massa input bahan divariasi menjadi $3 \mathrm{~kg}, 6$ $\mathrm{kg}$, dan $12 \mathrm{~kg}$ dengan kadar air awal bahan atau sampel $\left(\mathrm{M}_{\mathrm{ib}}\right)$ dianggap seragam atau konstan yaitu $37 \%$ bb . Kadar air awal bahan diukur dengan metode oven. Setiap sampel perlakuan tersebut, dialirkan ke dalam pengering AFB melalui hopper pengumpan yang digerakkan oleh motor listrik 1 fase. Suhu di dalam ruang pengering diatur sesuai dengan suhu perlakuan yaitu $50^{\circ} \mathrm{C}, 60^{\circ} \mathrm{C}$, dan $70^{\circ} \mathrm{C}$ yang diukur menggunakan termometer digital dengan sensor suhu termokopel tipe K. Variasi suhu dilakukan dengan cara mengatur massa atau bobot bahan bakar biomassa tempurung kelapa di dalam ruang pembakaran pada tungku biomassa. Selama proses pengeringan atau pengujian pengering $A F B$, dilakukan pengamatan terhadap suhu udara yang keluar dari pengering AFB $\left(\mathrm{T}_{\mathrm{op}}\right)$, suhu lingkungan $\left(\mathrm{T}_{\text {ling }}\right), \mathrm{RH}$ lingkungan, massa bahan bakar biomassa tempurung kelapa yang digunakan selama pengeringan $\left(\mathrm{m}_{\mathrm{bb}}\right)$, waktu pengeringan ( $\mathrm{t}$ ), dan kadar air akhir bahan $\left(\mathrm{M}_{\mathrm{ob}}\right)$. Suhu $\mathrm{T}_{\mathrm{op}}$ dan $\mathrm{T}_{\text {ling }}$ diukur secara langsung menggunakan thermometer digital yang dilengkapi sensor termokopel tipe $\mathrm{K}, \mathrm{RH}$ lingkungan diukur dengan $\mathrm{RH}$ meter digital, dan kadar air akhir bahan $\left(\mathrm{M}_{\mathrm{ob}}\right)$ diukur menggunakan metode gravimetri (metode oven). Letak pengukuran suhu dan beberapa variabel pengamatan lainnya dapat dilihat sesuai skema pengering AFB pada Gambar 1. Adapun konstruksi pengering AFB dapat dilihat pada Gambar 2.

\section{Analisis Data}

Analisis data yang digunakan untuk menentukan nilai indeks kinerja (HUF, COP, EHE) dan kebutuhan energi (SEC) pengering AFB adalah analisis matematis. Hasil analisis matematis tersebut, disajikan dalam bentuk grafik dan dibahas secara deskriptif. Nilai HUF, COP dan EHE dinyatakan dalam persentase (\%), sedangkan nilai SEC dinyatakan dalam satuan kilo joule $(\mathrm{kJ})$. Nilai HUF, COP, dan EHE ditentukan menggunakan Persamaan 1 sampai 3 (Chakraverty dan De, 1981). Sedangkan nilai SEC ditentukan menggunakan Persamaan 4 dan 5 (Prakash dkk., 2016).

$$
\begin{aligned}
& H U F=\frac{T_{u}-T_{o p}}{T_{u}-T_{\text {ling }}} x 100 \% \\
& C O P=\frac{T_{p}-T_{\text {ling }}}{T_{u}-T_{\text {ling }}} x 100 \% . \\
& \text { EHE }=\frac{T_{u}-T_{o p}}{T_{u}-T_{\text {wib }}} x 100 \% \ldots \\
& \text { SEC }=\frac{E_{\text {tot }}}{m_{a}}=\frac{E_{b b}+E_{L}}{m_{a}} \ldots \\
& m_{a}=\frac{t\left(M_{i}-M_{o}\right)}{100-M_{o}} \ldots \ldots . .
\end{aligned}
$$

dimana $\mathrm{T}_{\mathrm{u}}$ adalah suhu udara pengering $\left({ }^{\circ} \mathrm{C}\right)$, $\mathrm{T}_{\mathrm{op}}$ adalah suhu udara yang keluar dari pengering $\left({ }^{\circ} \mathrm{C}\right), \mathrm{T}_{\text {ling }}$ adalah suhu udara luar atau lingkungan $\left({ }^{\circ} \mathrm{C}\right), \mathrm{T}_{\text {wib }}$ adalah suhu udara pengering bola basah (wet bulb) $\left({ }^{\circ} \mathrm{C}\right), \mathrm{E}_{\mathrm{tot}}\left(\mathrm{E}_{\mathrm{bb}}\right.$ $+\mathrm{E}_{\mathrm{L}}$ ) adalah jumlah konsumsi energi $(\mathrm{kJ})$ yang digunakan oleh pengering $\mathrm{AFB}, \mathrm{E}_{\mathrm{bb}}$ energi bahan bakar biomassa berupa tempurung kelapa $(\mathrm{kJ})$ dan $\mathrm{E}_{\mathrm{L}}$ enegi listrik $(\mathrm{kJ})$, $\mathrm{t}$ adalah waktu pengeringan $(\mathrm{s}), \mathrm{m}_{\mathrm{a}}$ adalah massa air yang dipindahkan $(\mathrm{kg} / \mathrm{s}), \mathrm{M}_{\mathrm{ib}}$ adalah kadar air awal (\%bb), serta $\mathrm{M}_{\mathrm{ob}}$ adalah kadar air akhir pati sagu kering (\%bb). 


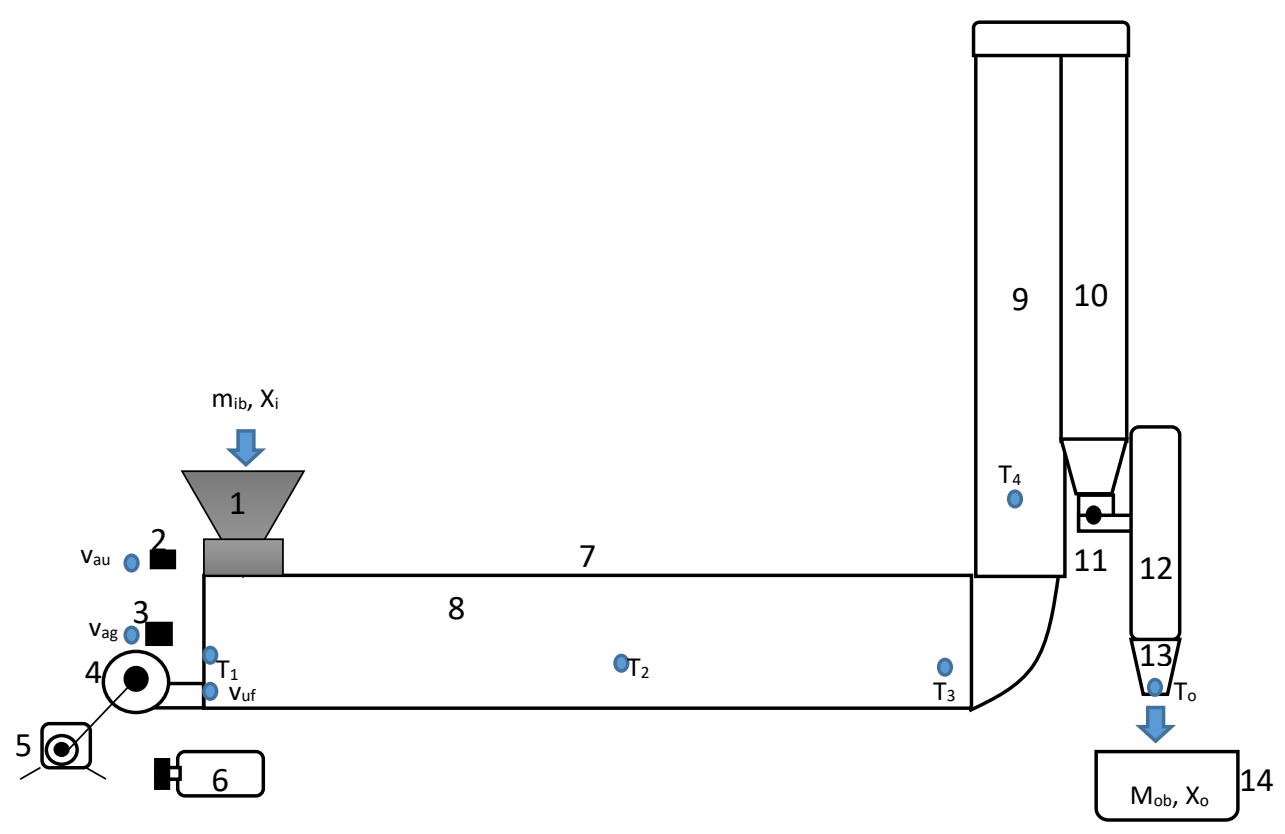

Keterangan: 1. Hopper dan silinder pengumpan (input bahan), 2. Poros dan pulley silinder pengumpan, 3. Poros dan pulley pengaduk (agitator), 4. Blower, 5. Motor listrik penggerak blower (1 fasa 220V $1 \mathrm{HP}$ ), 6. Motor listrik penggerak balingbaling pengaduk dan silinder pengumpan (3 fasa $2 \mathrm{HP}$ ), 7. Silinder agitator, 8. Baling-baling agitator, 9. Ruang pengering upriser, 10. Ruang pengering downcomer, 11. Blower sentrifugal, 12. Siklon pemisah, 13. Output bahan kering, 14. Tempat penampung bahan kering, $\mathrm{T}_{1-3}$ : suhu udara pengering, $\mathrm{T}_{\mathrm{o}}$ : suhu output, $\mathrm{K}_{\mathrm{a}}$ : kadar air awal bahan, $\mathrm{X}_{\mathrm{o}}$ : kadar air akhir bahan, $\mathrm{m}_{\mathrm{ib}}$ : massa bahan input, $\mathrm{m}_{\mathrm{bf}}$ : massa bahan output

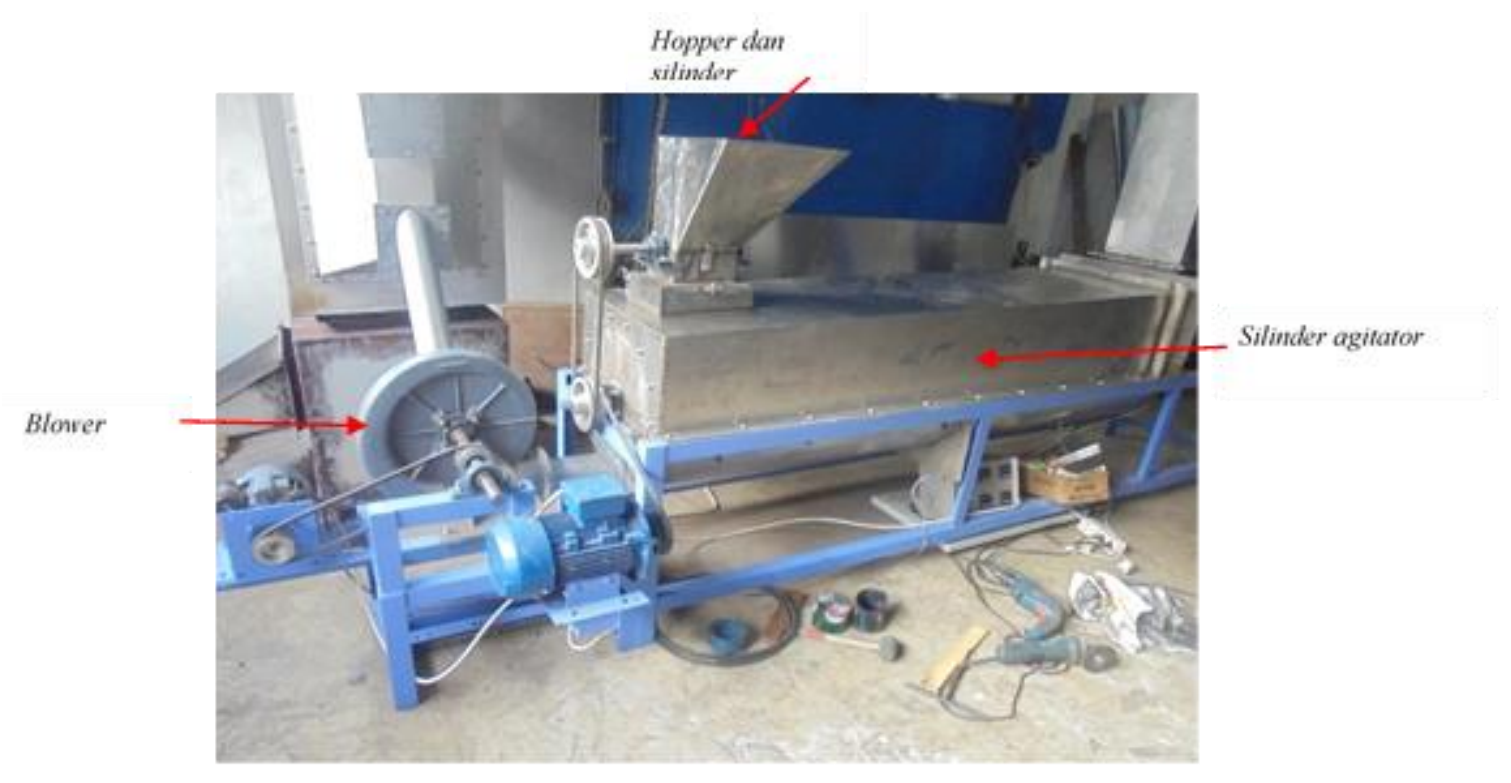

Gambar 2. Konstruksi pengering Agitated Fluidized Bed (AFB) 


\section{HASIL DAN PEMBAHASAN}

Data yang diperoleh dari hasil pengamatan selama pengujian kinerja pengering AFB dengan perlakuan suhu dan massa bahan input meliputi kadar air akhir rata-rata pati sagu kering $\left(\mathrm{M}_{\mathrm{ob}}\right)$ sebesar $14,4 \%$, waktu pengeringan rata-rata (t) sebesar $300 \mathrm{~s}$, suhu udara yang keluar dari pengering $\left(\mathrm{T}_{\mathrm{op}}\right.$ ), dan massa konsumsi bahan bakar biomassa tempurung kelapa $\left(\mathrm{m}_{\mathrm{bb}}\right)$. Nilai $\mathrm{t}, \mathrm{T}_{\mathrm{op}}$, dan $\mathrm{m}_{\mathrm{bb}}$ bervariasi sesuai dengan perlakuan suhu dan massa input bahan. Data-data tersebut digunakan dalam analisis matematis untuk menentukan nilai HUF, COP, EHE, dan SEC sesuai dengan Persamaan 1 sampai 5. Hasil analisis nilai indeks kinerja (HUF, COP, EHE) dan kebutuhan energi (SEC) pengering AFB disajikan dalam bentuk grafik pada pada Gambar 3 sampai 6.

Gambar 3 menunjukkan perbandingan nilai HUF dengan massa input bahan $\left(\mathrm{m}_{\mathrm{ib}}\right)$ sebanyak $3 \mathrm{~kg}$ pada setiap perubahan suhu udara pengering $\left(\mathrm{T}_{\mathrm{u}}\right) 50^{\circ} \mathrm{C}, 60^{\circ} \mathrm{C}, 70^{\circ} \mathrm{C}$ masing-masing adalah 42,9\%, 37,5\%, 41,5\%. Nilai COP pada massa bahan input dan perlakuan suhu yang sama adalah $57,1 \%$, $62,5 \%, 58,5 \%$, dan nilai EHE adalah 56,4, $61,2 \%$, dan $65,1 \%$. Data-data tersebut menunjukkan bahwa perubahan suhu di dalam ruang pengering selama proses pengeringan mempengaruhi nilai HUF, COP, dan EHE. Nilai HUF paling tinggi pada perlakuan suhu udara pengering $50^{\circ} \mathrm{C}$. Hal ini menunjukkan bahwa suhu perlakuan $50^{\circ} \mathrm{C}$ mampu mengeringkan pati sagu sebanyak $3 \mathrm{~kg}$.

Hubungan antara nilai HUF, COP, dan EHE pada pengering AFB dengan massa input bahan $\left(\mathrm{m}_{\mathrm{ib}}\right)$ sebanyak $3 \mathrm{~kg}$ pada setiap perubahan suhu udara pengering $\left(\mathrm{T}_{\mathrm{u}}\right) 50^{\circ} \mathrm{C}$, $60^{\circ} \mathrm{C}, 70^{\circ} \mathrm{C}$ juga disajikan pada Gambar 3. Pada suhu $50^{\circ} \mathrm{C}$, diperoleh nilai HUF, COP, dan EHE masing-masing sebesar 42,9\%, $57,1 \%$, dan $56,4 \%$. Pada suhu $60^{\circ} \mathrm{C}$ adalah $37,5 \%, 62,5 \%$, dan $61,2 \%$, pada suhu $70^{\circ} \mathrm{C}$ adalah $41,5 \%, 58,5 \%$, dan $65,1 \%$. Data tersebut menunjukkan bahwa pada setiap perlakuan suhu, nilai HUF lebih kecil dari nilai COP, begitupula dengan nilai EHE juga cukup kecil. Oleh karena itu, udara panas di dalam ruang pengering belum digunakan atau dimanfaatkan sepenuhnya untuk mengeringkan pati sagu sebanyak $3 \mathrm{~kg}$. Suhu udara yang keluar dari pengering lebih tinggi dari pada suhu udara lingkungan.

$\square 50$ oC $\square 60$ oC $\square 70$ oC

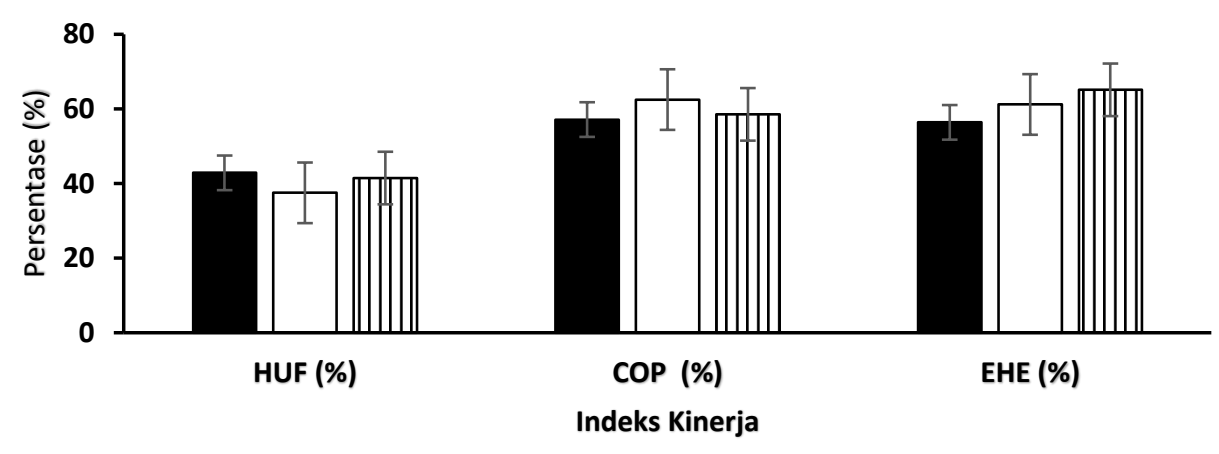

Keterangan: UHF : Heat utilization factor
COP: coefficient of performance
EHE: effective heat efficiency

Gambar 3. Variasi suhu $50^{\circ}, 60^{\circ} \mathrm{C}$ dan $70^{\circ} \mathrm{C}$ dengan massa bahan input $3 \mathrm{~kg}$ 
Gambar 4 menunjukkan perbandingan nilai HUF dengan massa input bahan $\left(\mathrm{m}_{\mathrm{ib}}\right)$ sebanyak $6 \mathrm{~kg}$ pada setiap perlakuan suhu udara pengering $\left(\mathrm{T}_{\mathrm{u}}\right) 50^{\circ} \mathrm{C}, 60^{\circ} \mathrm{C}$, dan $70^{\circ} \mathrm{C}$. Nilai HUF pada masing-masing perlakuan suhu tersebut adalah $14,1 \%, 29 \%$, dan $41,5 \%$. Nilai COP $85,7 \%, 70,9 \%, 58,5 \%$, dan nilai EHE 29,7\%, 54,7\%, 68,9\%. Selain itu, hubungan nilai HUF, COP, dan EHE juga disajikan pada Gambar 4.

Nilai HUF, COP, dan EHE pada suhu $50^{\circ} \mathrm{C}$ masing-masing adalah $14,1 \%, 85,7 \%$, dan $29,7 \%$. Pada suhu $60^{\circ} \mathrm{C}$ nilai HUF, COP, dan EHE adalah 29\%, 70,9\%, dan 54,7\%. Sedangkan pada suhu $70^{\circ} \mathrm{C}$ nilai HUF, COP dan EHE adalah 41,5\%, 58,5\%, dan 68,9\%. Data tersebut menunjukkan bahwa nilai HUF tertinggi pada suhu $70^{\circ} \mathrm{C}$ yaitu $41,5 \%$. Hal ini menunjukkan bahwa suhu terbaik untuk mengeringkan pati sagu sebanyak $6 \mathrm{~kg}$ adalah suhu $70^{\circ} \mathrm{C}$, walapun nilai nilai HUF lebih kecil dari nilai COP. Namun demikian, nilai HUF pada suhu tersebut lebih tinggi dari nilai HUF dari perlakuan suhu lainnya.
Gambar 5 menunjukkan nilai HUF pada suhu $50^{\circ} \mathrm{C}, 60^{\circ} \mathrm{C}$, dan $70^{\circ} \mathrm{C}$ dengan massa bahan $12 \mathrm{~kg}$ masing-masing sebesar $39,1 \%$, $53,1 \%$, dan $36,6 \%$. Nilai COP $60,9 \%, 46,9 \%$, dan $63,4 \%$. Sedangkan nilai EHE adalah $56,3 \%, 70,3 \%$, dan $64,1 \%$. Selain itu, Gambar 5 menyajikan data hubungan antara nilai HUF, COP dan EHE. Pada suhu $50^{\circ} \mathrm{C}$ nilai HUF, COP, dan EHE masing-masing adalah $39,1 \%$, $60,9 \%, 56,3 \%$. Pada suhu $60^{\circ} \mathrm{C}$ adalah $53,1 \%$, $46,9 \%, 70,3 \%$, dan suhu $70^{\circ} \mathrm{C}$ adalah $36,6 \%$, $63,4 \%, 64,1 \%$.

Data tersebut menunjukkan bahwa suhu terbaik untuk mengeringkan massa pati sagu sebesar $12 \mathrm{~kg}$ adalah pada perlakuan suhu $60^{\circ} \mathrm{C}$. Hal ini ditunjukkan dengan nilai HUF yang paling tinggi pada suhu perlakuan tersebut. Dengan menggunakan suhu tersebut, maka nilai indeks pengering AFB cukup baik, dimana nilai HUF lebih besar dari nilai COP sehingga nilai EHE menjadi lebih besar. Oleh karena itu, nilai indeks pengering AFB terbaik pada suhu $60^{\circ} \mathrm{C}$ dengan massa bahan $12 \mathrm{~kg}$, apabila dibandingkan dengan perlakuan suhu dan massa input bahan lainnya.

$\square 50$ oC $\square 60$ oC $\square 70$ oC

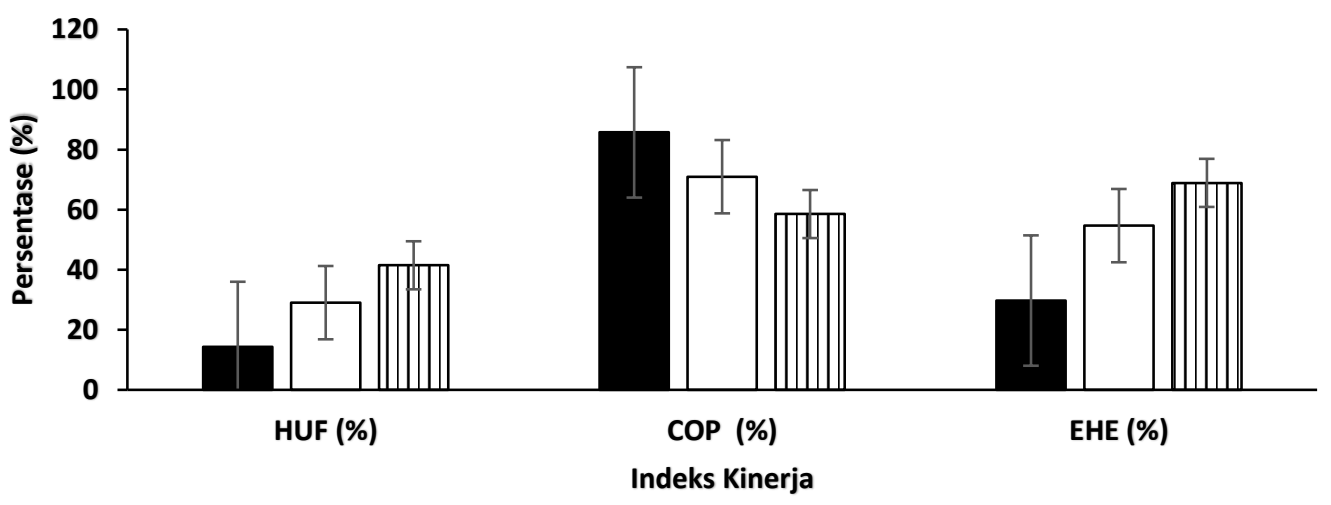

Keterangan: UHF : Heat utilization factor COP: coefficient of performance EHE: effective heat efficiency

Gambar 4. Variasi suhu $50^{\circ} \mathrm{C}, 60^{\circ} \mathrm{C}$, dan $70^{\circ} \mathrm{C}$ dengan massa bahan input $6 \mathrm{~kg}$ 
$\square 50$ oC $\square 60$ oC $\square 70$ oC

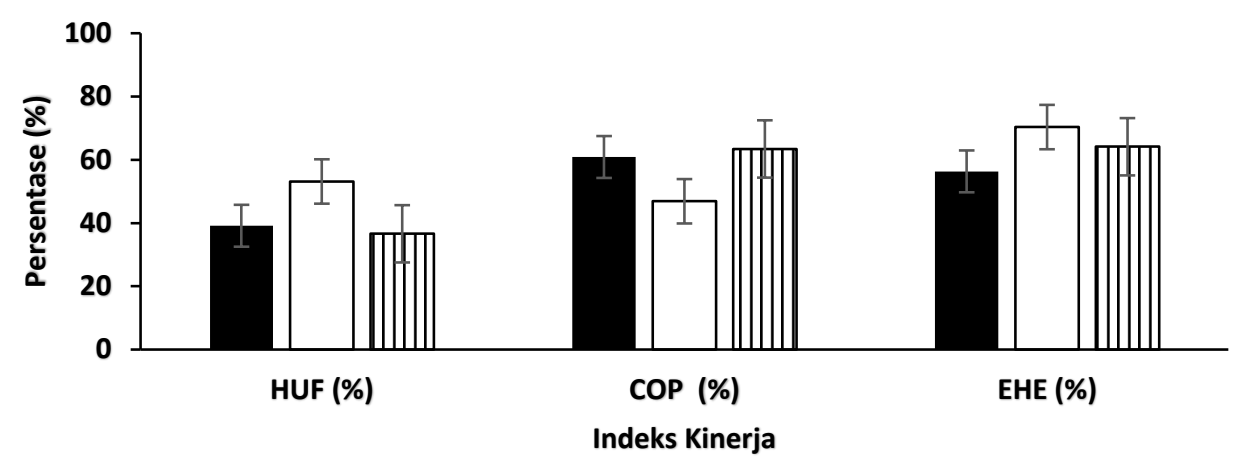

Keterangan: UHF : Heat utilization factor
COP: coefficient of performance
EHE: effective heat efficiency

Gambar 5. Variasi suhu $50^{\circ} \mathrm{C}, 60^{\circ} \mathrm{C}$, dan $70^{\circ} \mathrm{C}$ dengan massa bahan input $12 \mathrm{~kg}$

Nilai HUF, COP, dan EHE pada Gambar 3 sampai 5 mengalami perubahan yang tidak linear pada setiap perlakuan suhu (suhu variasi) dan massa bahan input, hal ini diduga karena pengaturan suhu yang diinginkan (suhu setting) di dalam ruang pengering AFB sangat sulit dilakukan untuk mencapai nilai konstan. Suhu dalam ruang pengering mengalami perubahan yang sangat cepat. Penyebabnya adalah suhu yang masuk ke dalam ruang pengering adalah suhu yang dihasilkan oleh tungku biomassa, sehingga sangat bervariasi. Menurut Jading dkk. (2014a) pengaturan suhu di dalam tungku pengering berbahan bakar biomassa sangat ditentukan oleh proses pengumpanan bahan bakar, sehingga sangat sulit untuk mendapatkan suhu konstan dalam ruang pengering. Selanjutnya Jading dkk. (2014b) mengemukakan bahwa untuk mempertahankan suhu di dalam ruang agitator dan vibrator pengering AGRO Cross Flow Fluidized Bed, maka dilakukan pengumpanan bahan bakar secara kontinyu dalam ruang pembakaran.

Data yang disajikan pada Gambar 3 sampai 5 menunjukkan bahwa nilai HUF pada setiap perlakuan suhu dan massa bahan input lebih kecil dari nilai COP. Hal ini menunjukkan bahwa penggunaan udara panas di dalam ruang pengering AFB pada setiap perlakuan suhu dan massa input bahan kurang efektif sehingga nilai EHE yang dihasilkan kurang dari $80 \%$. Menurut Chakraverty dan De
(1981), nilai EHE suatu pengering umumnya lebih besar atau sama dengan $80 \%$.

Nilai indeks kinerja pengering AFB secara keseluruhan dapat dilihat berdasarkan nilai rata-rata $\mathrm{HUF}$, COP, dan EHE pada semua variabel perlakuan. Adapun nilai ratarata HUF, COP dan EHE tersebut masingmasing adalah $37,23 \%, 62,7 \%$, dan 58,5\%. Dari nilai rata-rata tersebut menunjukkan bahwa kinerja pengering AFB cukup rendah, dimana nilai HUF rata-rata lebih kecil dari nilai COP rata-rata. Nilai HUF seharusnya lebih besar dari nilai COP. Semakin kecil nilai COP, maka semakin baik kinerja suatu pengering. Hal tersebut tercapai jika suhu udara keluar sama dengan suhu udara lingkungan, maka pengeringan tersebut dianggap baik. Semua panas yang dihembuskan dari suhu input dapat diserap dengan sempurna oleh pengering, sehingga kinerja pengering dalam memanfaatkan panas juga akan baik. Penjumlahan antara nilai HUF dengan COP sama dengan satu. Sedangkan nilai EHE mempertimbangkan panas sensibel pada udara pengering sebagai panas yang efektif untuk pengeringan (Chakraverty dan De, 1981).

Nilai indeks kinerja pengering AFB dapat dibandingkan dengan nilai indeks kinerja beberapa pengering buatan lainnya. Nilai HUF, COP, dan EHE pengering PCD resirkulasi bahan secara berkelanjutan yaitu $70,383 \%$, 29,617\%, dan 78,819\% (Jading dkk., 2017b). Hasil penelitian lainnya yang dilakukan oleh 
Alam dan Sehgal (2014) menunjukkan bahwa nilai HUF, COP, dan EHE pengering trolley cum batch dryer yaitu 52\%, 51,5\%, dan 40,4\%. Sayyad dkk. (2015) juga telah menentukan nilai HUF dan COP solar cooker cum dryer yaitu 0,1-0,57 (10-57\%) dan 0,430,8 (43-80\%). Prakash dkk. (2006) juga telah menentukan nilai HUF dan COP green house dyer masing-masing adalah 0,12-0,53 (12$53 \%$ ) dan 0,55-0,87 (55-87\%). Dari hasil perbandingan tersebut, menunjukkan bahwa nilai indeks kinerja pengering AFB lebih rendah apabila dibandingkan dengan pengering-pengering lainnya tersebut. Hal ini diduga disebabkan belum efektifnya rancangan tungku biomassa yang digunakan sebagai sumber pemanas pada pengering AFB, terutama pada proses pengumpanan bahan bakar biomassa. Oleh karena itu, panas yang masuk ke dalam ruang pengering tidak dapat diatur secara konstan, sehingga panas yang dihasilkan oleh tungku biomassa yang masuk ke dalam ruang pengering tidak termanfaatkan secara maksimal atau banyak yang terbuang.

Selain itu, konstruksi ruang pengeringan pada pengering AFB belum dilengkapi dengan isolator sehingga panas yang tersedia tidak sepenuhnya digunakan selama proses pengeringan, memungkinkan panas tersebut banyak terbuang ke udara. Hal ini menyebabkan nilai HUF rata-rata lebih kecil dari nilai COP rata-rata. Menurut Jading dkk. (2017a) nilai HUF adalah rasio antara penurunan suhu karena pendinginan udara yang diakibatkan oleh penggunaan panas pada pengering dengan kenaikan suhu karena pemanasan udara selama proses pengeringan.

Nilai indeks kinerja pengering akan mempengaruhi kebutuhan energi (SEC) selama proses pengeringan. Nilai indeks kinerja yang kecil akan membutuhkan energi yang besar untuk mengeringkan bahan selama proses pengeringan. Nilai SEC pengering AFB berdasarkan perlakuan suhu dan massa input bahan, dapat dilihat pada Gambar 6. Besarnya nilai SEC yang dibutuhkan untuk mengeringkan $3 \mathrm{~kg}, 6 \mathrm{~kg}$, dan $12 \mathrm{~kg}$ pati sagu basah dengan kadar air awal $37 \%$ bb menjadi $14,47 \%$ bb masing-masing adalah 154,5-56,2 $\mathrm{kJ} / \mathrm{s}, 292,89-296,98 \mathrm{~kJ} / \mathrm{s}$, dan 569,28-559,95 $\mathrm{kJ} / \mathrm{kg}$. Dari data tersebut menunjukkan bahwa semakin berat (massa) pati sagu basah yang dikeringkan semakin besar energi yang dibutuhkan. Ketebalan bahan dalam ruang pengering juga mempengaruhi waktu pengeringan sehingga membutuhkan energi yang cukup besar. Hal ini disebabkan oleh jumlah massa air yang dipindahkan bertambah seiring dengan bertambahnya massa (berat) bahan (Prakash dkk., 2016; Jading dkk., 2016).

Perubahan suhu di dalam ruang pengering AFB tidak banyak berpengaruh terhadap nilai SEC, seperti ditunjukkan pada Gambar 6. Hal ini menunjukkan bahwa perubahan suhu $50-70^{\circ} \mathrm{C}$ tidak mempengaruhi kebutuhan energi selama proses pengeringan. Penyebabnya diduga karena perubahan suhu di dalam ruang pengering cukup kecil, seperti halnya hasil penelitian yang dilakukan oleh Nimmol dan Devahastin (2010).

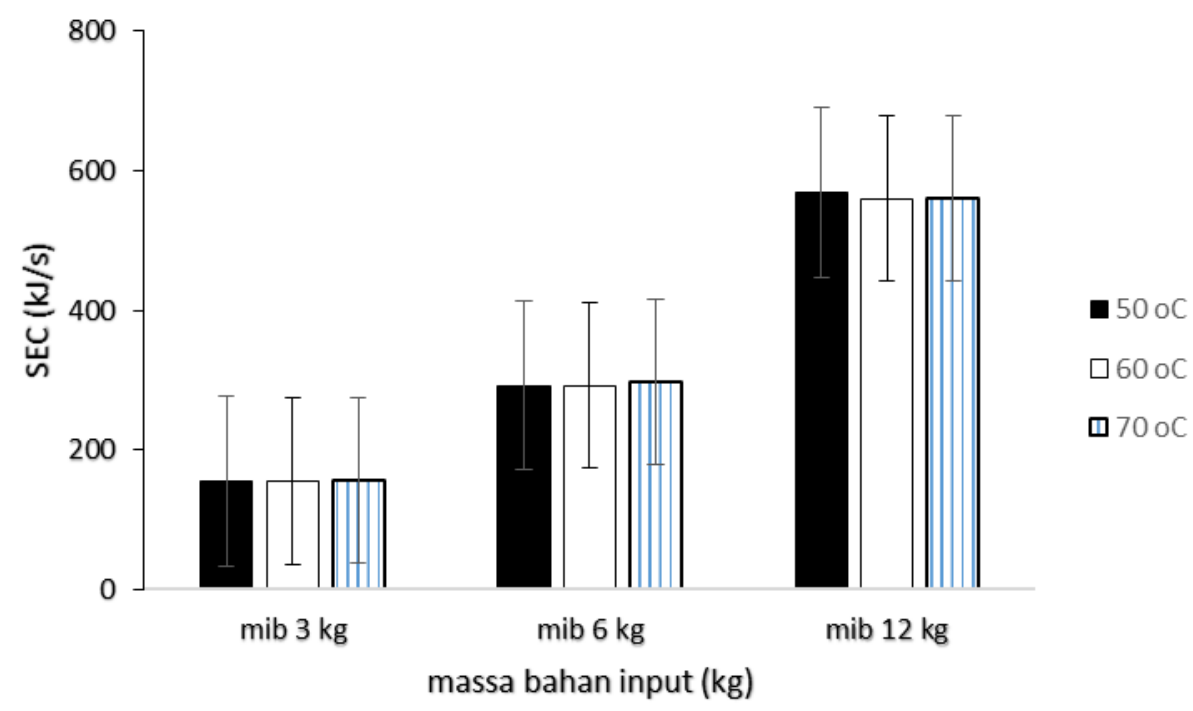

Gambar 6. Nilai kebutuhan energi dengan variasi suhu dan massa bahan input 


\section{KESIMPULAN}

Indeks kinerja pengering AFB terbaik dari semua perlakuan suhu dan massa input bahan adalah pada suhu $60^{\circ} \mathrm{C}$ dengan massa input bahan $12 \mathrm{~kg}$, dimana nilai HUF lebih besar dari nilai COP. Nilai HUF, COP dan EHE masing-masing yaitu $53,1 \%, 46,9 \%$, $70,3 \%$ dengan kebutuhan energi SEC sebesar $559,9 \mathrm{~kJ} / \mathrm{s}$. Sedangkan indeks kinerja keseluruhan pengering AFB berdasarkan perlakuan suhu dan massa input bahan adalah nilai HUF rata-rata, COP rata-rata, dan EHE rata-rata masing-masing adalah 37,23\%, $62,7 \%, 58,5 \%$. Nilai rata-rata kebutuhan energi (SEC) untuk mengeringkan pati sagu basah sebanyak 3-12 kg dengan kadar air awal 37\% bb menjadi $14,47 \%$ bb yaitu $337,6 \mathrm{~kJ} / \mathrm{s}$. Hal ini menunjukkan bahwa nilai HUF rata-rata lebih kecil daripada nilai COP rata-rata pada pengering $\mathrm{AFB}$, dan energi yang digunakan cukup tinggi sehingga nilai EHE kurang dari 80\%, menyebabkan kinerja pengering AFB cukup rendah. Hal ini disebabkan konstruksi tungku biomassa yang digunakan belum efektif mengalirkan udara panas ke dalam ruang pengering AFB. Selain itu, ruang pengeringan pada pengering AFB belum dilengkapi dengan isolator sehingga memungkinkan udara panas banyak terbuang ke udara. Oleh karena itu, perlu dilakukan penelitian lanjutan untuk pengembangan rancangan ruang pengeringan dan tungku biomassa sebagai sumber panas pada pengering AFB. Namun demikian, pada variasi suhu $70^{\circ} \mathrm{C}$ dengan massa bahan $3 \mathrm{~kg}$ selama 5 menit (300 detik), pengering AFB mampu mengeringkan pati sagu dengan kadar air akhir 14,4\% basis basah mendekati standar mutu pati sagu kering $13 \%$.

\section{UCAPAN TERIMA KASIH}

Penulis mengucapkan terima kasih kepada Direktorat Riset dan Pengabdian Kepada Masyarakat, Kementerian Riset, Teknologi, dan Pendidikan Tinggi (KEMRISTEKDIKTI) yang telah memberikan bantuan dana penelitian melalui skema Penelitian Fundamental tahun 2015, dengan nomor kontrak: 089/SP2H/LT/DRPM/IV/ 2015.

\section{DAFTAR PUSTAKA}

Alam, M.S., and Sehgal, V.K., (2014), Development and Evaluation of TrolleyCum-Batch Dryer for Paddy, International Journal Advances in Engineering \& Technology, 7(3), pp. 756-764.

Chakraverty, A., and De, D.S., (1981), Post Harvest Technology. Oxford \& IBH Publishing Co., New Delhi, pp. 49-51.

Jading, A., Bintoro, N., Sutiarso, L., dan Karyadi, J.N.W., (2017a), Evaluation of The Performance of Pneumatic Conveying Recirculated Dryer for Drying of Flours Materials. Proceeding of ISAE Seminar. Bandar Lampung, 1012 Agustus 2017. pp. 1-8.

Jading, A., Bintoro, N., Sutiarso, L., dan Karyadi, J.N.W., (2016), Analisis Efisiensi Pneumatic Conveying Recirculated Dryer untuk Pengeringan Bahan-Bahan Tepung. Prosiding Seminar Nasional Fakultas Pertanian Universitas Veteran Yogyakarta. Yogyakarta, 10 Desember 2016, pp. 370-378.

Jading, A., Payung, P., dan Tethool, E.F., (2017b), Alat Pengering Pati Berbasis Sagu dan Umbi-umbian Model Unggun Terfluidisasi, I.D. Paten No. IDS000001633.

Jading, A., Payung, P., dan Reniana, (2014a), Kajian Teknis-Ekonomis Alat Pengering Pati Sagu Model Cross Flow Vibro Fluidized Bed, Agritech, 34(4), pp. 448455.

Jading, A., Payung, P., Aman, W.P., dan Tethool, E.F., (2013), Pengembangan Rancangan Agitator untuk Mengoptimumkan Aliran Bahan pada Alat Pengering Pati Sagu Model Agitated-Vibro Cross Flow Fluidized Bed (AGROCFFB). Prosiding Seminar Nasional Perhimpunan Teknik Pertanian. Denpasar, 13-14 Juli 2014, pp. 463-469.

Jading, A., Payung, P., Aman, W.P., dan Tethool, E.F., (2014b), Pengembangan dan Analisis Teknis-Finansial Alat Pengering Pati Sagu Model Agro Cross Flow Fluidized untuk Menunjang Agroindustri Sagu di Papua, Jurnal 
Teknologi Industri Pertanian, 24(2), pp. 137-147.

Jading, A., Payung, P., dan Tethool, E.F., (2015), Studi Eksperimental dan Pemodelan Pengeringan Pati Sagu Berbasis Jaringan Syaraf Tiruan pada Pengering Agitated Fluidized Bed, Laporan Penelitian, LPPM Universitas Papua, Manokwari, Tidak dipublikasikan.

Nimmol, C., and Devahastin, S., (2010), Evaluation of Performance and Energy Consumption of an Impinging Stream Dryer for Paddy, Applied Thermal Engineering, 30, pp. 2204-2212.
Pradhapraj, M., and Velmurugan, V., (2014), Experimental Investigation of Solar Air Heater with Charcoal Porous Medium, Asian Journal of Scientific Research, 7, pp. 56-65.

Prakash, O., Kumar, A., and Laguri V., (2016), Performance of Modified Greenhouse Dryer with Thermal Energy Storage, Energy Reports, 2, pp. 155-162.

Sayyad, F.G., Sardar, N.R., Rathod, J.P., Baria, U.A., Yaduvanshi, B.K., Solanki, B.P., and Chavda, J.J., (2015), Design and Development of Solar Cooker Cum Dryer, An International Research Journal of Environmental Science, 10, pp. 985-993. 